\title{
STUDENTS TRAINING - FUTURE TEACHERS OF EARLY SCHOOL EDUCATION FOR WORK IN CULTURALLY DIVERSIFIED ENVIRONMENT
}

\author{
Ewa Ogrodzka-Mazur \\ Doktor habilitowany, Profesor \\ University of Silesia in Katowice \\ Faculty of Ethnology and Educational Science \\ Institute of Education \\ ul. Bielska 62, 43-400 Cieszyn, Poland \\ eom1@wp.pl
}

\section{ABSTRACT}

Referring to theoretical assumptions of pedagogy and intercultural education, the discussion was undertaken on their implementation by students - future teachers working with I-III class children in Cieszyn Silesia. The following issues were focused on: (1) the occurrence and role of elements of intercultural education in teaching children, (2) the range of teaching contents, (3) the implemented programmes and those in the process of preparation. The analysis was also carried out of teachers' expert preparation and their professional training and improvement concerning the implementation of intercultural education.

Key words: students - future teachers; early school education; multicultural environment; multi- and intercultural education.

\section{INTRODUCTION}

Functioning of school in the environment of multicultural borderland (where people from different cultures, nations or ethnic groups are the participants of education) is associated with the necessity to specify new roles and tasks of this institution, as well as to indicate the competences the acquisition of which will enable teachers and learners' genuine participation in community life. Due to developmental properties of the child in lower classes, the undertaken actions should enhance creating such curriculum of early school education in which the following goals concerning shaping the learner's competence are implemented (Hanisz, 1999, pp. 4-5; Lewowicki, 2000, pp. 14-22; Lewowicki, 2015, pp. 24-33): communicating with people; cooperation and coexistence with people; using active methods of learning socio-cultural reality; distinguishing, describing and explaining the relation between natural constituents of wildlife environment and human life and activity; shaping the attitude of both the recipient of works of art and their future author; shaping the attitude of both the user of technological products and their future inventor.

The suggested model of education appears to be particularly beneficial for the child at early school age - it seems to facilitate multisided and harmonious development of the child's personality, as - according to M. Jakowicka «education cannot be described any longer as acquiring certain contents of knowledge. It should be understood in its essence as the process of the existence 
of man, who - owing to the variety of experience - learns how to express oneself, how to communicate, how to ask the world questions and how to fulfill oneself in an unceasing way» (Jakowicka, 1994, p. 31; Jakowicka, 2000, pp. 136-145). In this way, the aims of integrated education agree with fundamental aspects of modern teaching, which (in compliance with the assumptions of J. Delors's Report) may become life-long pillars of each individual's knowledge. These pillars involve: to learn in order to know (to acquire knowledge tools for understanding facts and phenomena), to learn in order to act (to acquire competences enabling communication and work with others, as well as conflict regulation and solving), to learn in order to live together (to learn coexistence, discovering oneself from the Other's perspective, aiming at the same goals), and to learn in order to be (to discover and experience oneself in different forms of expression and creative engagement (Delors, 1998, pp. 85-97).

The birth of multicultural societies becomes a new prospect for formulating tasks and expectations from contemporary early school education which concern shaping cultural competences of all participants in the educational process (learners, teachers, and parents) who function in a particular socio-cultural reality. In this context, what becomes an important issue is searching for a model (models) of teacher training. The existing standards of teachers' professional competences, which take into account the modern aspect of functioning of educational systems and which are comprised in the set of so called key competences (moral, praxeological, communicative, cooperative, creative and informative), seem to be insufficient in pedagogical activities conducted in borderland areas.

\section{MODERN CONCEPTS OF THE CHILD AND CHILDHOOD - RESEARCH POINTS OF VIEW}

Complexity of intercultural education allows for focusing on these cultural and cognitive categories which nowadays might be included in the discussion on shaping the identity of early school education and on the new quality of integrated education in lower classes. Applying a particular cultural and cognitive perspective in interpreting educational processes and changes which occur in early school education indicates the essence of the social function of childhood. This function consists in «the revealing by people at this social age, in this stage of their biography, of subject-oriented possibilities of participation in a social configuration with which they are identified and in which consecutive acts of their life scenario (determined by historically and currently shaped life prospects) are created and fulfilled» (Modrzewski, 2000, p. 355). The activeness manifested in this way allows the child also for conducting value judgments of observed facts and phenomena in the surrounding socio-cultural reality and thus becomes an important marker of the child's personal and cognitive development. These developmental achievements constitute the main goals of contemporary educational teleology.

Modern concepts of the child and childhood are created in the process of social discourse, which is changeable in time and cultural space. Referring to approaches applied in pedagogy, humanistic psychology and sociology, five parallel (in their functions) constructions (visions) of the child and childhood are distinguished according to G. Dahlberg, P. Moss and A. Pencea's typology:

- The child as a reconstructor of knowledge, identity and culture (J. Locke's child) - the construction of the child as a tabula rasa - an empty card which 
should be written with knowledge, skills and competences. It corresponds to the transmission concept of identity, culture and education.

- The child as a naïve, infantile, good, defenseless, illogical creature (J. J. Rousseau's child) - such construction of the child which assumes the necessity of environmental influence (both instrumental and subject-oriented) on the child's development.

- The child as a creature determined by biology and universal stages of development ( $\mathrm{J}$. Piaget's child) - the construction of the child who develops independently from the socio-cultural context (the past, present day and future) but normalized or defined by maturity or developmental stages.

- The child as a factor of work market - in three perspectives: a) as a tool for creating jobs for education workers, b) as an element of future labour force, c) as an element of well-educated and working mothers and fathers.

- The child as a creator of knowledge, identity and culture - such construction of the child which assumes the participation in the dialogue concerning one's own identity, the construction of culture and the impact on it (Dahlberg, Moss, \& Pence, 2001; Karwowska-Struczyk, 2007, pp. 33-41).

The first four visions of the child and childhood are reflected in educational institutions and contemporary school still remains rather an environment oriented towards the transmission of public knowledge (monologue education) than a place favouring communication and referring to children's personal knowledge and their individual experience - dialogue education (Klus-Sta ska, 2002). Teachers' practical activities focus on these levels of shaping broadly understood children's competences which are indicated by the programme, methodologically easier to introduce and do not require their personal cognitive-emotional engagement. Moreover, the school model based on transmission, not communication, results in the fact that understanding the development does not trigger teachers' designing educational situations which enhance collecting and working on learners' experiences of their own activity. These experiences undergo the processes of structuring and restructuring in the whole life cycle (Tyszkowa, 1988, p. 48; Tyszkowa, 1993). Thus, referring to the title of M. Dudzikowa's book, the myth of school as a place of the learner's «multisided development» and of a large dissonance between theory and practice can still be discussed. What also remains is still rather a distant (both in theory and educational practice) vision of the child as a creator of knowledge, identity and culture. Chances for its fulfillment are brought about along with intercultural education, which is based on a different axiology and social politics and which results from noticing the needs and expectations of individuals and groups.

\section{TOWARDS INTERCULTURAL EDUCATION}

J. Nikitorowicz defines intercultural education as «the whole of mutual influences and effects of individuals, groups, institutions, organizations, associations, and unions which facilitate such human development which aims at man's becoming a fully aware and creative member of family, local, regional, religious, national, continental, cultural, global, or planetary community and which enable man's active self-fulfillment and unique, lasting identity and unlikeness» (Nikitorowicz, 2003, pp. 44-45; Nikitorowicz, 2008). Applying such understanding of the idea of intercultural education, its aims can be indicated: 
1. In the field of attitudes: viewing the society as a complex of coexisting and intersecting groups and individuals reaching the limits of their separateness and unlikeness; raising tolerance and self-control in response to difference and respecting it in all regards; raising sensitiveness to other cultures and to their integral values and patterns which enrich general culture; abandoning the feeling of cultural superiority, nationalism, ethnicism, prejudice and stereotyping, tendencies to exoticism and xenophilia; opposing all forms of xenophobia, discrimination, racism, hostility, etc. towards Others/Aliens; empathy, openness to the World, engagement oriented towards peace, equality, brotherhood and solidarity in each environment and promoting a just world with no exploitation, oppression or hunger.

2. In the field of skills: noticing, distinguishing and understanding cultural differences and one's own dignity and value in contacts with Others/Aliens; selfacceptance in spite of the perceived differences; viewing unlikeness as enriching, stimulating, interesting and absorbing, but not threatening or hostile; familiarizing with and understanding Others/Aliens as inevitable neighbours; leaving the centre of one's own culture, inner development through the liquidation of barriers and borders; conscious entering the borderlands and cultural contact areas within intercultural communication; recognizing signs of inequality, injustice, discrimination, marginalization, racism, stereotyping and prejudice against Others/Aliens; favouring and strengthening mutual relations between different communities, especially between cultural or ethnic majority and minority groups; initiating mechanisms helpful in solving problems originated by differentiation, prejudice, negative attitudes and stereotypes; peaceful coexistence despite differences and contradictory interests and the tension and conflicts which result from them.

3. In the field of awareness: objective and equal status and rights of all cultures; one's own identity, value, separateness, independence; one's own cultural roots, traditions, customs; group, family, ethnic, local, cultural, regional, national, super-national, global bonds; ecologism - in the context of natural environment and society (Grzybowski, 2007, pp. 80-81).

Indicating such numerous aims for intercultural education signifies the awareness of extended social expectations from the agents responsible for its implementation (parents and teachers). On the other hand, this is associated with the need of introducing intercultural education and the education towards interculturalism from the earliest educational stages - in pre- and early school education.

\section{IN SEARCH FOR THE MODEL (NEW MODELS) OF INTERCULTURAL EARLY SCHOOL PEDAGOGY}

Searching for the model (models) of modern intercultural pedagogy becomes an important educational challenge and a frequent subject of expert research. Intercultural pedagogy is most often approached in these studies as: 1) ars educandi, related to educational practice and comprising actually performed educational activities; 2) detailed pedagogy, which is a theoretical and scientific reflection upon educational practice and which possesses its own subject matter, system of notions and methodology (Grzybowski, 2007, p. 116). 
In P. Denoux's (1995) approach, the major problem issues of intercultural education comprise:

- identity (cultural, ethnic and intercultural) - its shaping, personality and differences; attitudes, stereotypes, prejudice, tension, conflicts (especially on the majority - minority contact front); teaching/learning the identification, deconstruction and acceptance of differences;

- the existence of clearly distinct cultural groups;

- cultural borderland in the context of multi- and interculturalism (its character, range, problems, prospects, etc.), viewed both intra- and internationally; processes which take place in borderlands - introduction, acceptance, adaptation, assimilation, integration, enculturation, cultural diffusion, rejection, marginalization, exclusion, stigmatization, (positive and negative) discrimination, transmission of cultural heritage; individuals' being torn apart between two (or more) systems of meanings and its consequences both for individuals themselves and for their environment; factors which alleviate or eliminate problems concerning intercultural communication and understanding and factors which facilitate this communication; dialogue, its conditions and course;

- $\quad$ the effects of people's moving from one cultural environment to another (e.g. work seekers, tourists, sportspeople, members of families scattered in different countries);

- $\quad$ social, educational, etc. policy of different agents to cultural minorities; the situation and prospects of immigrants, their children and the accepting societies in relations with them; the situation of individuals and environments out of favour due to difference; rights of (cultural, educational, social, etc.) minorities and majorities;

- relations between traditional cultures and postmodernist culture and virtual and national ones;

- the situation of the educational system and its particular elements in the culturally differentiated environment; the manifestation of stereotypes and prejudice in course books, media, literature, etc.; political correctness; hidden programme; handling cultural differentiation in school curricula; inner cultural differentiation of schools, recognition of learners' cultural identity; educating teachers; activities (contents, methodology, etc.) and their effects within formal and informal intercultural education (pp. 161-173).

Intercultural early school pedagogy implemented in the conditions of cultural differentiation takes into account both the transition from ars educandi to pedagogy and the above discussed comprehension of key areas of intercultural pedagogy. Coming back to «the roots», to the paradigms of the child's early education, to «absent discourses», it indicates a new way of re-organizing pedagogical work with the child at early school age, which is interpreted in the categories of «the help in development, mutual help and education for development». Thus, the intercultural perspective in early school pedagogy constitutes two intersecting paths. The determinant of the first is the knowledge leading from familiarization with (a new code of culture) to understanding another culture («I know what the new code means»). The second path refers to human interactions and leads from the hypothesis of the contact with the Other to cultural training «imagine you are the Other» (Kamińska, 2007, p. 79). Due to the undertaken considerations, what becomes particularly significant is specifying cultural and cognitive contexts of intercultural early school pedagogy, which might be applied in teachers' educational activity. 


\section{CULTURAL CONTEXTS}

\section{Relation: child - culture - education}

According to I. Wojnar, culture (viewed nowadays as «not only the heritage, the universum of creative acts of mankind, but also as the humanistic quality of human activity and lifestyle) becomes the basic educational authority corresponding to a new educational demand which is being born. Education is a way to make culture real - first of all 'the culture in people'. Thus, education and culture determine each other - education enlightens and culture differentiates (as 'an effect' of education), which results in an ongoing process of developing culture itself» (Wojnar, 1996, p. 25; Lewowicki, 2004, pp. 42-47; Olbrycht, 2000, pp. 63-70). In approaching the relation child - culture - education, intercultural early school pedagogy applies the cultural orientation, which links the sphere of culture with values and personal selfdevelopment and which emphasizes the individual's liberty and self-identification (being a subject). In accordance with this: 1) the individual is independent from culture, which consists in the freedom of applying an attitude to it (outside or within oneself) and to possible cultural determinism. One of the forms of applying this attitude is self-awareness. This liberty constitutes the specificity and essence of man; 2) the specifically human way of existence is in fact the orientation towards values as possible elements of culture. The individual anticipates them and makes them concrete, whereas the elements attract the individual. This is not freedom towards culture but within it (Jagoszewska, 1995, p. 26; Ogrodzka-Mazur, 2007; Ogrodzka-Mazur, 2016, pp. 54-86).

In the suggested approach, what should be important in the child's early education are the processes of culturation, as well as of primary and secondary socialization. On one hand, they enable rooting into culture (the assimilation of the existing cultural values) and gaining a particular place in the community. On the other hand, owing to the individual's self-fulfillment abilities, they allow individuals to «create» new, socially accepted values, in the form of cultural products, and, in this way, to create a «new» quality of the group's or community's culture.

\section{Building the feeling of multidimensional cultural identity}

Forming the child's feeling of multidimensional cultural identity in the individual (self-oriented) and social (outer) perspective occurs in the area of: a) «I» condition, b) the concept of oneself in the world, and c) competences concerning activity (possible contacts with the world and relations with Others). At the same time, this process is a kind of self-identification which the child must be able both to develop along with gradual maturing and to re-define during the whole life. The individual's orientation in the surrounding cultural reality, which develops in this way, finds its representation in the system of «meanings» formulated in particular family, school, and out-of-school situations by people who are important for the individual. These meanings become a source of different values (and their possible «interpretations»), which come into being, and of developing the ability to judge the acquired knowledge and experience. Among others, the following are the sources of information about oneself, which might become the foundation of shaping the feeling of identity of the child at early school age in natural and constructed educational situations: observing one's own behaviour and its consequences; observing other people's behaviour and comparing to these people; obtaining information directly from other people (others' opinions about 
myself); social categorizations associated with belonging to particular social groups (categories) - e.g. family, school, peer group, region, nation, Europe, or the world; an insight into one's own personality.

III. Sensitization to the Other and noticing unlikeness of people from other cultures - towards the modification of ethnic stereotypes and prejudice

As H. Pietrzak (2000) notices, stereotyping, most frequently experienced by children in interpersonal and group relations, concerns both individuals and groups or the whole societies but it starts and ends with the individual's own experience. «It is the individual's consciousness where generalizations and attributions appear as a result of specific cognitive processes. Evaluating their meaning, the role of perception as the leading process (constituting the base for informative and consciousness-related transformations of other kinds) is usually highlighted» (p. 105). The perception of the social world in late childhood comprises learners' already acquired knowledge of co-occurring different human qualities and the knowledge of different types of people and their typical behaviour patterns (which results in an individual way of perceiving Others). This process also involves stereotypes and prejudices, which function among children and are signs of their negative attitude to others, including ethnic groups and nations. The results of the studies carried out in this problem area confirm the occurrence of all kinds of stereotypes and prejudices at all age levels of children from 7 to 13 years. The analysis of empirical data concerning Polish learners allow for stating that they have a well-crystallized and rather strongly negative attitude to most national minorities in Poland and that the applied attitudes of unwillingness towards others maintain for a long time, contrary to their peers from Western Europe.

Referring to B. Weigl's and W. Łukaszewski's experimental studies on the modification of stereotypes and prejudices of early school learners in Opole enables to confirm both children's evident proneness to influences which shape negative attitudes to alien ethnic groups or nations and their susceptibility to activities which weaken such prejudice and stereotypes (Weigl, 1999, p. 31). This creates an opportunity for undertaking educational activities aiming at «weakening» the established negative stereotypes and prejudices and their modification.

\section{Intercultural communication and dialogue}

«Being» in one's own culture and understanding other cultures is based on language, which, for the child, is at the same time 'a tool' for communicating with the surroundings, 'the material' for creative activity, and an object of exploration. Over the last decades, due appreciation of the pragmatic factor has drawn the researchers' attention to the analysis of the development of children's talk in the aspect of the processes of social communication. Along with the children's acquisition of speaking (of specific language codes), they acquire the requirements of the social structure in which they live. The child's experience is transformed as a result of learning, which is the effect of the child's own, seemingly random, speech acts. «In this way, social structure becomes a substrate of the child's experience, which comes into being through many different linguistic processes» (Kozielecki, 1997, p. 208). From this point of view, it should be assumed that each time the child speaks or listens to others' talk, a process occurs which strengthens social structure and forms the child's cultural identity. This phenomenon can also have the following interpretation - individuals achieve control over their social roles through the process of communication. 
Children's functioning in the culturally differentiated borderland environment provides them with regular linguistic contacts with their peers - members of other communities and societies, and it quite frequently creates natural situations enhancing simultaneous participation in two cultures and two linguistic systems. Bilingualism, acquired in this way, may have the «adding» (enabling high competence in both languages) or «subtracting» character, in which the more prestigious language (of the majority or dominating culture) replaces the first language (of the minority culture) and does not let the individual achieve proper fluency in any of them (Czykwin, \& Misiejuk, 2002).

\section{COGNITIVE CONTEXTS}

\section{Motivation for familiarizing with the world and learning}

Developing children's cognitive processes and their orientation in the environment is an important aim of education also in its pre-school stage. This development is characterized by intensive motivation for familiarizing with the surrounding world of people, things and phenomena, as well as for acquiring (in the process of learning) social competences which determine the efficiency of the child's functioning in social situations at school and outside it. Developmental theories, which emphasize the cultural and social context of teaching and learning, highlight the role and significance of the double social structure in which the child participates - that is both the relation with peers (the children's world) and the «objective reality» - created, established and imposed by adults (Berger, \& Luckmann, 1983; Erikson, 2000; Łaciak, 2011). The dichotomous nature of the child's functioning in two social words also brings about the necessity to fulfill the child's basic needs which appear in the process of:

- $\quad$ symbiosis (tight teaming up and union with the nearest environment) the need for bonds, closeness and acceptance (in relations with others), which determines the feeling of safety in the human world;

- $\quad$ separation (gradual emerging of I out of the symbiotic unity) - the need for identity, which enables creating the borderline I - Other people;

- individualization (developing the inner I autonomy) - the need for selffulfilment, the exploration of the surroundings, and independent activity, which presents the expression of one's own I (Małkiewicz, 2002, pp. 16-17).

The distinguished needs of bonds, identity and self-fulfillment become the basic determinants of the pace, dynamics and direction of children's cognitive activeness (including their own creative activity). This activeness allows the child for a very close relation with the nearer and further cultural environment, which also enhances "building" the representation of one's own person (among other factors, associated with preserving one's own identity and with maintaining or increasing one's own position in the social system of meanings (Reykowski, 1990, p. 47).

\section{Constructing knowledge at school: learning through intercultural dialogue and contact}

Intercultural early school pedagogy necessitates a different approach to the child's acquisition of knowledge - to the transition from monologue education to dialogue education, which involves generating meanings. As J. Bruner (1996), the author of the notion 'interpretative phrase' emphasizes, «generating meanings is linked with placing the meetings with the world in their appropriate cultural context in order to learn 'what is it about?'. Although meanings are in the mind, 
they have their source and references in the culture in which they are created. This cultural situating of meanings ensures their negotiating nature and immersion in communication. Whether there are 'private meanings' is not an issue here; what is important is that meanings provide a basis for cultural exchange. From this point of view, cognition and communication are, in their essence, highly interrelated, in fact inseparable» (p. 3). This assumption results in changes in educational theories which concern such areas as (Klus-Stańska, 2002, pp. 65-67): the teacher's knowledge - a significant role of personal pedagogical theories, personal reflection upon one's own practice, the focus on the alternative status of educational solutions; the learner's knowledge - the existence of many «possible worlds» and their interpretations, the understanding dialogue, being ready for «disobedience in thinking», creative thinking, the school's hidden programme; classroom communication - the social character of learning, cooperation in group aiming at the same goal (task), the searching-creative function of speech, the significance of explorative speech (thinking aloud); didactic planning - spontaneous experimenting, guidelines, improvisation, and goals understood as intentions and general plans.

According to J. Bruner's (2006) concept of education, the thesis treating culture as both the basic orientation of modern pedagogy and education and as the need for cultural enhancement results in defining school as the learning culture. Its fundamental task is supporting children in learning the use of tools for generating meanings and in their adjustment to the world and in changing this world dependently on the needs. Such learning culture should also contribute to shaping learners' identity and self-esteem, as well as it should strengthen the chances for managing at school and outside it (pp. 23-68).

\section{ENDING - THE PROSPECTS FOR THE DEVELOPMENT OF INTERCULTURAL EARLY SCHOOL PEDAGOGY}

The undertaken discussion urges to formulate final conclusions which will indicate the prospects for the development of intercultural early school pedagogy, taking into account both its possibilities and limitations:

- $\quad$ in the field of pedagogical theory: promoting the paradigms «education for development» and «coexistence», focusing on basic and applied studies in the area of so called directional development of children at early school age in the context of changing socio-cultural surroundings; relating intercultural studies to the latest currents in philosophy, psychology, sociology, science of culture and other disciplines;

- $\quad$ in the field of educational practice: preparing students - future teachers for the role of an intercultural guide and interpreter, broadening the range of integration in I - III classes: a) integration of common activities of the teacher and child, b) integration of the class team, c) integration of the child's life environments (family, peer group, school), d) integration of educational and cultural offers (at school and outside it).

What cannot be forgotten is the key role in intercultural education of teachers' personal competences. The simplified model of the competence of intercultural adaptation comprises: empathy, respect, flexibility of roles, orientation towards knowledge, interactive attitude and management, and tolerance for ambiguity (Gajdzica, 2013; Lewowicki, Ogrodzka-Mazur, \& Szczurek-Boruta, 2008; 
Ogrodzka-Mazur, \& Gajdzica, 2015, pp. 487-497; Szczurek-Boruta, 2014). Thus, openness to new experience and new people becomes indispensable, as well as the knowledge of foreign languages, communication skills and appearance.

Expert and methodological preparation of I - III class teachers for implementing intercultural contents becomes another necessity. Genuine familiarizing with this subject matter will enable both teachers and learners to understand contemporary (multi)cultural processes and to «respond» to the needs of particular culturally differentiated local communities in order to «last as a nation with its specific values and, at the same time, to take active part in the process of integration, not vanishing culturally in the Union and the global world» (Nikitorowicz, 1999, p. 30).

\section{REFERENCES}

Berger, P., \& Luckmann, T. (1983). Społeczne tworzenie rzeczywistości. Warszawa, Polska: PIW.

Bruner, J. S. (2006). Kultura edukacji. Kraków, Polska: Universitas.

Bruner, J. S. (1996). The culture of education. Cambridge, UK: London Harward University Press.

Czykwin, E., \& Misiejuk, D. (2002). Dwujęzyczność $i$ dwoukulturowość w perspektywie psychopedago-gicznej. Białystok, Polska: Wydawnictwo Uniwersyteckie «Trans Humana».

Dahlberg, G., Moss, P., \& Pence, A. (2001). Quality in early childhood education. Postmoderne perspectives. London, UK: Routledge Falmer, Taylor\&Francis Inc.

Delors, J. (1998). Edukacja: jest w niej ukryty skarb. Raport dla UNESCO Międzynarodowej Komisji do spraw Edukacji dla XXI wieku. Warszawa, Polska: SOP.

Denoux, P. (1995). La recherche interculturelle en France. W: M. AbdallahPretceille, A. Thomas (Eds.): Relations et apprentissages interculturels. Paris, France.

Erikson, E. H. (2000). Dzieciństwo i spoleczeństwo. Poznań, Polska: Dom Wydawniczy «Rebis».

Gajdzica, A. (2013). Portret zbiorowy nauczycieli aktywnych - między zaangażowaniem a oporem wobec zmian. Cieszyn - Torun, Polska: Wydział Etnologii i Nauk o Edukacji Uniwersytetu Śląskiego, Wydawnictwo Adam Marszałek.

Grzybowski, P. P. (2007). Edukacja europejska - od wielokulturowości ku międzykulturowości. Kraków, Polska: Oficyna Wydawnicza «Impuls».

Hanisz, J. (1999). Program wczesnoszkolnej zintegrowanej edukacji XXI wieku. Klasy 1-3. Warszawa, Polska: WsiP.

Jagoszewska, J. (1995). Jednostka ludzka i jej relacje do kultury w psychologii humanistycznej. In: S. Pietraszko (Ed.): Kultura a jednostka ludzka. Prace Kulturoznazcze $V$. Wrocław, Polska: UW.

Jakowicka, M. (2000). Integracja jako jedna z głównych idei jakościowego aspektu edukacji na XXI wiek. In: G. Miłkowska-Olejniczak, K. Uździcki (Eds): Pedagogika wobec przemian i reform oświatowych. Zielona Góra, Polska: WSP.

Jakowicka, M. (1994). Kształcenie dla rozwoju - zmiana i nowe obszary w badaniach edukacyjnych i działalności praktycznej. In: S. Palka (Ed.): 
Teoretyczne odniesienia i praktyczne rozwiazania w pedagogice wczesnoszkolnej. Katowice, Polska: «Śląsk».

Kamińska, K. (2007). Nauczyciel wychowania przedszkolnego wobec wielokulturowości. Łódź, Polska: UŁ.

Karwowska-Struczyk, M. (2007). Dziecko i konteksty jego rozwoju. Warszawa, Polska: IBE.

Klus-Stańska, D. (2002). Konstruowanie wiedzy w szkole. Olsztyn, Polska: UWM.

Kozielecki, J. (1997). Koncepcje psychologiczne człowieka. Warszawa, Polska: Wydawnictwo Akademickie «Żak».

Lewowicki, T., Ogrodzka-Mazur, E., \& Szczurek-Boruta, A. (Eds.) (2008). Praca nauczyciela w warunkach wielokulturowości - studia i doświadczenia z pogranicza polsko-czeskiego. Cieszyn - Warszawa - Toruń, Polska: Wydział Etnologii i Nauk o Edukacji UŚ, Wyższa Szkoła Pedagogiczna ZNP w Warszawie, Wydawnictwo Adam Marszałek.

Lewowicki, T. (2004). Kultura, wartości i edukacja - o humanistycznej synergii i racjonalnym optymizmie. In: D. Kubinowski (Ed.): Kultura - Wartości Ksztatcenie. Toruń, Polska: Adam Marszałek.

Lewowicki, T. (2000). Światowe tendencje a stan i perspektywy edukacji wczesnoszkolnej w Polsce. In: W. Puślecki (Ed.): Ksztatcenie wczesnoszkolne na przetomie tysiacleci. Warszawa: PAN KNP.

Łaciak, B. (red.). (2011). Nowe spoleczne wymiary dzieciństwa. Warszawa, Polska: Wydawnictwo Akademickie «Żak».

Lewowicki, T. (2015). Intercultural education - from assimilation to integration and multidimensional identity. In: H. Kyuchukov, T. Lewowicki, E. OgrodzkaMazur (Eds.): Intercultural education - concepts, practice, problems. Munich, Polska: LINCOM Academic Publishers.

Małkiewicz, E. (2002). Motywy poznawania świata i uczenia się w kontekście podstawowych potrzeb dziecka. In: M. Kochan-Wójcik, A. Krajna, Z. Kuklińska, E. Małkiewicz (Eds): Edukacja elementarna a diagnoza pedagogiczna. Warszawa, Polska: CODN.

Modrzewski, J. (2000). Aktualność społecznej kwestii dzieciństwa. In: G. Miłkowska-Olejniczak, K. Uździcki (Eds): Pedagogika wobec przemian $i$ reform oświatowych. Zielona Góra, Polska: WSP.

Nikitorowicz, J. (1999). Projektowanie edukacji międzykulturowej w perspektywie demokratyzacji i integracji europejskiej. In: J. Nikitorowicz, M. Sobecki (Eds): Edukacja międzykulturowa w wymiarze instytucjonalnym. Białystok, Polska: Wydawnictwo Uniwersyteckie "Trans Humana”.

Nikitorowicz, J. (2003). Wartości etnosu jako podstawa kształtowania tożsamości wielokulturowej, podłoże konfliktów kulturowych i cel edukacji międzykulturowej. In: T. Lewowicki, E. Ogrodzka-Mazur, A. Gajdzica (Eds): Świat wartości i edukacja międzykulturowa. Cieszyn - Warszawa, Polska: UŚ Filia w Cieszynie, Wyższa Szkoła Pedagogiczna ZNP w Warszawie.

Nikitorowicz, J. (2008). Edukacja regionalna i międzykulturowa. Warszawa, Polska: WaiP.

Ogrodzka-Mazur, E. (2007). Kompetencja aksjologiczna dzieci w młodszym wieku szkolnym. Studium porównawcze środowis zróżnicowanych kulturowo. Katowice, Polska: UŚ.

Ogrodzka-Mazur, E. (2016). The specificity of educating young learners in the culturally diversified environment. In: E. Ogrodzka-Mazur, B. Grabowska, 
A. Szafrańska-Gajdzica, Ł. Kwadrans. Education of children and youth in culturally diverse environments: experiences - problems - prospects. Munich, Polska: LINCOM Academic Publishers.

Ogrodzka-Mazur, E., \& Gajdzica, A. (2015). New professionalism' of the teacher and education towards interculturalism. International Journal of Continuing Engineering Education and Lifelong Learning. Vol. 25. № 4.

Olbrycht, K. (2000). Rola edukacji kulturalnej w budowaniu tożsamości kulturowej. In: T. Szkołut (Ed.): Sztuka i edukacja kulturalna w czasie przemian. Lublin, Polska: UMCS.

Pietrzak, H. (2000). Nastepstwa i efekty stereotypowego postrzegania człowieka $i$ śroiata społecznego. Rzeszów, Polska: WSP.

Reykowski, J. (1990). Rozwój moralny jako zjawisko wielowymiarowe. In: J. Reykowski, N. Eisenberg, E. Staub (Eds): Indywidualne i społeczne royznaczniki wartościowania. Wrocław, Polska: Zakład Narodowy im. Ossolińskich.

Szczurek-Boruta, A. O (2014). Przygotowaniu nauczycieli do pracy w warunkach wielokulturowości: konteksty, opinie studentów, propozycje. Torun - Katowice, Polska: Wydawnictwo Adam Marszałek, UŚ.

Tyszkowa, M. (1993). Ekologiczne uwarunkowania rozwoju psychicznego jednostki: propozycja interpretacji poznawczej. Kwartalnik Polskiej Psychologii Rozтооотеј. Vol. 1. № 2.

Tyszkowa, M. (1988). Rozwój psychiczny jednostki jako proces strukturacji i restrukturacji doświadczenia. In: M. Tyszkowa (Ed.): Rozwój psychiczny człowieka w ciagu życia. Zagadnienia teoretyczne i metodologiczne. Warszawa, Polska: PWN.

Weigl, B. (1999). Stereotypy i uprzedzenia etniczne u dzieci i młodzieży. Studium empiryczne. Warszawa, Polska: IP PAN.

Wojnar, I. (1996). Aktualne problemy edukacji i kultury w Polsce i na świecie. In: I. Wojnar, J. Kubin (Eds): Edukacja wobec wyzwań XXI wieku. Warszawa, Polska: Komitet Prognoz «Polska w XXI wieku» przy Prezydium PAN. 